\title{
The Effect of Z-ion Zeolite Substrate on Growth of Zea mays L. as Energy Crop Growing on Marginal Soil
}

\author{
Mariola Chomczyńska1*, Magdalena Zdeb \\ ${ }^{1}$ Environmental Engineering Faculty, Lublin University of Technology, ul. Nadbystrzycka 40B, 20-618 Lublin, \\ Poland \\ * Corresponding author's e-mail: m.chomczynska@pollub.pl
}

\begin{abstract}
The presented study aimed at determining the influence of the increasing dose of new Z-ion zeolite substrate on the growth of maize (Zea mays L.) as species belonging to energy crops. In order to achieve the study aim, the pot experiment was carried out where the plants were grown on six series of media i.e.: on marginal soil (the control series I), on arable soil (the control series II) and on four mixtures of marginal soil with increasing Z-ion substrate addition $(1 \%, 2 \%, 5 \%, 10 \% \mathrm{v} / \mathrm{v})$. The pot test was carried out in a phytotron with a 13/11 light/dark regime. After the end of the experiment, the mean values of the vegetative parameters (wet and dry biomass of roots and stems) characterizing the plant growth in particular media series were determined. The $\mathrm{C}: \mathrm{N}$ ratio for maize stems was calculated as well. The obtained study results showed a favorable influence of Z-ion substrate additions on the vegetative growth of maize. Already a $1 \%(\mathrm{v} / \mathrm{v})$ substrate addition to marginal soil increased the wet and dry stems biomass by $173-204 \%$. At the same time, it turned out that in the sixth week of plant growth, a 5\% substrate addition to the marginal soil enables to achieve the value of vegetation parameters at a level similar to that of the parameters characterizing the plant development on arable land. Thus, at an early stage of plant growth, a $5 \%$ substrate dose can be considered as one allowing a similar course of maize growing on marginal soil as in the case of arable soil. It is worth noting that at this substrate dose, the $\mathrm{C}: \mathrm{N}$ ratio in maize stems reached the value of 13.05, at which the plant biomass is the substrate ensuring the fairly proper course of methane fermentation supplying fuel in the form of biogas.
\end{abstract}

Keywords: marginal soils, energy crops, Z-ion substrate

\section{INTRODUCTION}

The development of human civilization causes a faster and faster increase in energy demand. The energy system of the Earth is based on fossil fuels whose resources are limited in time and their use brings negative consequences for the natural environment [Comparetti et al. 2013, Lewandowski and Ryms 2013, Koszel and Lorencowicz 2015]. Therefore, geological, ecological, but also economic and political considerations related to the need for greater independence from foreign fuel suppliers, justify the requirement of increasing the share of renewable energy sources in primary energy production in Poland [Igliński et al. 2009]. In our country, among the renewable fuels, biomass which is also assessed as the least capital-intensive renewable energy source, occupies the largest share in energy production [Igliński et al. 2009]. The biomass used for energy production comes from various sources, inter alia, from the cultivation of energy plants that are directly incinerated or used for the production of liquid biofuels (e.g. rapeseed oil) or gas biofuels (e.g. biogas) [Lewandowski and Ryms 2013]. Energy crops can be grown on arable soils, but in the light of the reports of competition between food and energy crops and the resulting possible negative impact on food security, it is proposed to grow energy crops on degraded or marginal soils [Fritsche et al. 2010, FAO 2009, Nabel et al. 2014]. Marginal soils are defined as edaphic defective soils for anthropogenic or natural reasons, where it is impossible to obtain a yield at 
an economically justified level and with adequate food quality [Kościk 2003]. The cultivation of energy crops on such soils will often require the use of fertilizer materials. Such materials may include substrates prepared on the basis of natural and synthetic ion exchangers. These substrates were first prepared at the Institute of Physical and Organic Chemistry of the Belarusian Academy of Sciences in Minsk for the purpose of cultivating crops in closed ecological systems. In fact, they are mixtures of cation and anion exchangers loaded with plant nutrient ions in appropriate ratios and have obtained the trade name Biona ${ }^{\circledR}$ [Soldatov 2019, Chomczyńska et al. 2014]. Due to the high exchange capacity of ion exchangers, the nutrient content in substrates can be significantly higher than in the best natural soils. The macro- and micronutrients present in ion exchangers in high concentrations are not osmotically active; therefore, there is no possibility of causing damage to plant roots [Chomczyńska et al. 2016]. It was shown in the past studies that small additions of ion exchange substrates (at the level of $2 \% \mathrm{v} / \mathrm{v}$ ) to sand (as a degraded soil model) resulted in an increase in plant biomass in the range of 300-1400\% [Chomczyńska 2013]. Currently, the wide use of substrates prepared on the basis of synthetic ion exchangers is limited by financial considerations, mainly by the costs of production of anion exchange resins. Therefore, work was begun on the preparation of new substrates consisting only of cheaper natural ion exchangers, which are zeolites [Kosandrovich et al. 2019]. These substrates are prepared as mixtures of various ionic forms of clinoptilolite with the addition of weakly soluble calcium and magnesium phosphates. They are produced under "Z-ion" trade mark and their varieties differ in the nominal molar ratio of $\mathrm{NH}_{4}^{+} / \mathrm{K}^{+}=1 / 1-4 / 1$ and $\mathrm{pH}$ equal to 5,6 and 7. The concentration of nutrient ions in the solution equilibrated with the substrate is controlled by equivalent ion exchange of $\mathrm{K}^{+}$ and $\mathrm{NH}_{4}^{+}$ions with the plant metabolites and low solubility of the calcium and magnesium phosphates. This provides constant and safe for the plants total ionic concentration in the substrate solution independently of the amount of the zeolite substrate in the growing media [Kosandrovich et al. 2019].

In connection with the need to support the development of energy crops, the aim of the presented studies was to determine the effect of the dose of a new zeolite substrate on the course of vegetation of common maize (Zea mais L.). Maize is also an energy species whose above-ground biomass is used as a feedstock in the methane fermentation carried out in biogas production systems.

\section{MATERIALS AND METHODS}

Marginal soil, arable soil and Z-ion substrate were used as basic materials in the study. The marginal soil was taken from the excavation boundary of the sand mine in Rokitno, situated near Lublin (Eastern Poland). The $\mathrm{pH}$ value of the soil in $1 \mathrm{M}$ $\mathrm{KCl}$ solution was 4.3. The contents of macronutrients available for plants in the soil were determined according to the Polish standards [Lityński and Jurkowska 1982, Ostrowska et al. 1991]. It was characterized by low $(\mathrm{P}, \mathrm{S})$, very low $(\mathrm{K}, \mathrm{Mg})$ or insufficient $(\mathrm{N}, \mathrm{Ca})$ contents of nutrients in terms of plant requirements - Table 1 .

The arable soil was collected from the field situated in Czesławice, near Nałęczów (Eastern Poland). The $\mathrm{pH}$ value of the soil in $1 \mathrm{M} \mathrm{KCl}$ solution was 5.5. The contents of macronutrients available for plants in the soil were determined according to the Polish standards. It was characterized by very high or high $(\mathrm{P}, \mathrm{Mg})$, medium $(\mathrm{K})$, low (S) and insufficient $(\mathrm{N}, \mathrm{Ca})$ contents of nutrients in terms of the plant requirements - Table 1.

The Z-ion substrate was used as a nutrient carrier in the study. It was prepared at the experimental plant of "Project WISMUT" Ltd. (Russia). It constituted a mixture of ammonium form of clinoptilolite (about $75 \% \mathrm{v} / \mathrm{v}$ ), potassium form of clinoptilolite (about $25 \% \mathrm{v} / \mathrm{v}$ ) and weakly soluble $\mathrm{Ca}^{2+}$ and $\mathrm{Mg}^{2+}$ phosphates. The amounts of nutrients in the substrate were as follows $(\mathrm{mmol} / \mathrm{kg})$ : $\mathrm{N}-324, \mathrm{P}-100, \mathrm{~K}-110, \mathrm{Mg}-80, \mathrm{Ca}-113$, $\mathrm{S}-1.4, \mathrm{Na}-101$.

Table 1. Contents of nutrients in soils

\begin{tabular}{|c|c|c|c|c|c|c|c|}
\hline Soil & $\begin{array}{c}\mathrm{N}-\mathrm{NH}_{4} \\
{\left[\mathrm{mg} / \mathrm{dm}^{3}\right]}\end{array}$ & $\begin{array}{c}\mathrm{N}-\mathrm{NO}_{3} \\
{\left[\mathrm{mg} / \mathrm{dm}^{3}\right]}\end{array}$ & $\begin{array}{c}\mathrm{P}_{2} \mathrm{O}_{5} \\
{[\mathrm{mg} / 100 \mathrm{~g}]}\end{array}$ & $\begin{array}{c}\mathrm{K}_{2} \mathrm{O} \\
{[\mathrm{mg} / 100 \mathrm{~g}]}\end{array}$ & $\begin{array}{c}\mathrm{Mg} \\
{[\mathrm{mg} / 100 \mathrm{~g}]}\end{array}$ & $\begin{array}{c}\mathrm{Ca} \\
{\left[\mathrm{mg} / \mathrm{dm}^{3}\right]}\end{array}$ & $\begin{array}{c}\mathrm{S}_{-\mathrm{SO}_{4}} \\
{[\mathrm{mg} / 100 \mathrm{~g}]}\end{array}$ \\
\hline Marginal soil & 2.77 & 10.56 & 5.7 & 1.83 & 1.5 & 238.3 & 0.83 \\
\hline Arable soil & 3.07 & 9.76 & 34.9 & 19.7 & 7.75 & 586.0 & 0.49 \\
\hline
\end{tabular}


The studies were performed using maize (Zea mais L. cv. Bejm) as the test species. Six series of media were prepared for the purpose of the pot experiment, including: marginal soil (the control I), arable soil (the control II) and four marginal soil series with increasing Z-ion substrate doses $-1 \%, 2 \%, 5 \%, 10 \%(\mathrm{v} / \mathrm{v})$ - Table 2 . Before preparation of media series, calcium bicarbonate was added to marginal soil $(60 \mathrm{mg}$ of $\mathrm{CaCO}_{3}$ per $100 \mathrm{~g}$ of soil) to adjust its $\mathrm{pH}$ to the $\mathrm{pH}$ level of the arable soil.

The experiment started on 17th September 2018. In each pot (with the volume of $1200 \mathrm{~cm}^{3}$ ), one germinated seed was sown. The experiment was carried out in a phytotron with a 13/11 light/ dark regime. The daytime ( 7 a.m. -8 p.m.) air temperature was $25 \pm 1^{\circ} \mathrm{C}$, while the night-time (8 p.m.-7 a.m.) air temperature was $16 \pm 1^{\circ} \mathrm{C}$. During the experiment, the plants were watered with distilled water. The amount of water depended on the current needs of the plants. The experiment was terminated after 42 days from the time of seed sowing. The plant stems were cut down and roots were separated. The wet and $\operatorname{dry}\left(105^{\circ} \mathrm{C}\right)$ biomass of stems and dry $\left(105^{\circ} \mathrm{C}\right)$ root biomass were weighed. The total dry biomass of plants was calculated as a sum of dry stem and root biomass. In stem biomass the content of carbon and nitrogen was determined. The carbon content was analyzed with TOC SSM 5000A Shimadzu apparatus, while the nitrogen content was determined using Kjeltec ${ }^{\mathrm{TM}} 8200$ Foss Tecator equipment. The results obtained were used for the calculation of mean values characterizing the experimental series (arithmetical mean values). The data obtained on plant yield were subjected to analysis of variance (Statistica 12.5 software). The means were separated using Tukey's test at the 0.05 probability level [Wołek 2007]. In order to describe the relationship between the plants biomass and the substrate dose, linear and nonlinear (logarithmic) regression was used in three ranges of applied doses i.e.: $0-2 \%, 0-5 \%$ and $0-10 \%$.
The structural parameters of regression equations - mathematical models were estimated with the least-squares method [Zuur 2009]. In addition, the $\mathrm{R}^{2}$ coefficient and the Chow $\mathrm{F}$ statistics were determined to assess the quality of the regression fit to the analyzed data. The $\mathrm{R}^{2}$ coefficient expresses the level of explained variability of the dependent variable by the adopted mathematical model, while the Chow F statistics is used to test the significance of the differences between the model consisting only of the intercept and the adopted model. The higher the values of both statistics, the better the fit of the model to the analyzed data [Devore 2011, Wooldridge 2009].

\section{RESULTS AND DISCUSSION}

The study results on plant biomass are presented in Figures 1-8. It can be seen that already $1 \%$ substrate addition to marginal soil favorably affected maize growth increasing plant biomass significantly. In fact, wet and dry stem biomass, dry root biomass and total dry biomass of plants growing on soil enriched with $1 \%$ substrate dose was higher than that on marginal soil alone by 204, 171, 142 and 159\%, respectively (Fig. 1-4). With increasing substrate fraction in marginal soil, the vegetative parameters (particularly: wet and dry stem biomass, total dry biomass) increased logarithmically to a level of $10 \%$ substrate addition (Fig. 5-7), which is confirmed by very high values of the $\mathrm{R}^{2}$ coefficient obtained for regression equations $\mathrm{y}=\mathrm{a}_{2} \log (\mathrm{x}+1)+\mathrm{a}_{0}$ (Table 3-5). In the dose range of $0-2 \%$, the dependence of fresh and dry stem biomass and total dry plant biomass on the substrate dose can be determined by the linear regression, because the differences in $\mathrm{R}^{2}$ values calculated for linear and logarithmic models, indicating differences in the levels of explained variance by these models, were the smallest and did not exceed 3.5\% (Table 3-5). Similarly, the absolute values of differences in

Table 2. Characteristics of media series in the pot experiment

\begin{tabular}{|l|c|c|}
\hline \multicolumn{1}{|c|}{ Media series } & $\begin{array}{c}\text { Soil } \\
{\left[\mathrm{cm}^{3} / \mathrm{pot}\right]}\end{array}$ & $\begin{array}{c}\text { Substrate addition } \\
{\left[\mathrm{cm}^{3} / \mathrm{pot}\right]}\end{array}$ \\
\hline Marginal soil (MS) & 1150 & - \\
\hline Arable soil (AS) & 1150 & - \\
\hline Marginal soil+1\% Z-ion (MS+1\%) & 1138 & 11.5 \\
\hline Marginal soil+2\% Z-ion (MS+2\%) & 1127 & 5 \\
\hline Marginal soil+5\% Z-ion (MS+5\%) & 1092 & 57.5 \\
\hline Marginal soil+10\% Z-ion (MS+10\%) & 1035 & 5 \\
\hline
\end{tabular}




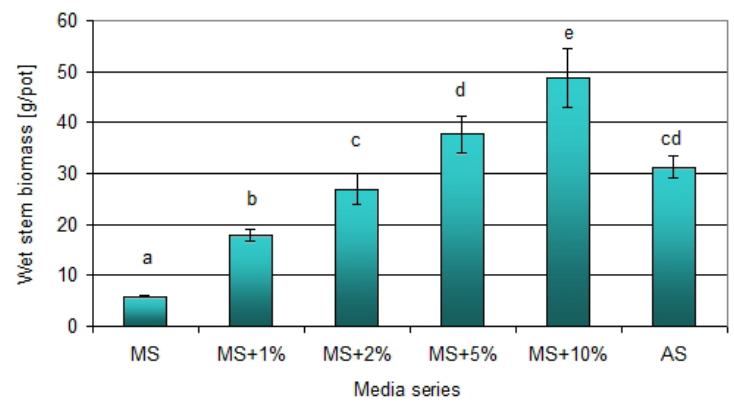

Fig. 1. Wet stem biomass of maize in media series of pot experiment; explanations: MS - marginal soil, MS $+1 \%$ - marginal soil with $1 \%$ Z-ion addition, MS $+2 \%$ - marginal soil with $2 \%$ Z-ion addition, MS $+5 \%$ - marginal soil with 5\% Z-ion addition, MS $+10 \%$ - marginal soil with $10 \%$ Z-ion addition, AS - arable soil, I - standard deviation, the mean values with the same letter are not significantly different

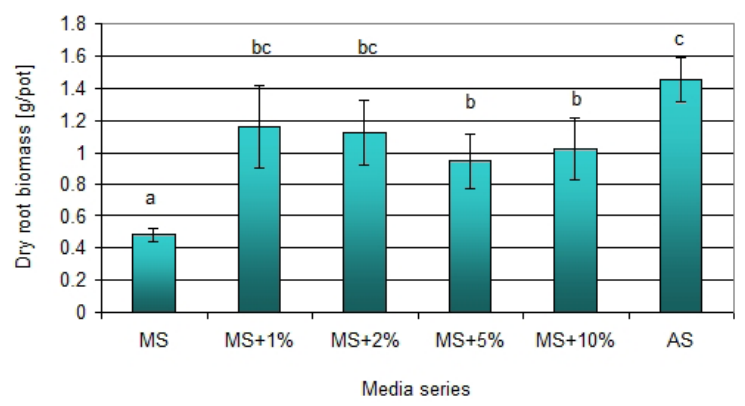

Fig. 3. Dry root biomass of maize in media series of pot experiment; explanations are the same as under Fig. 1

the Chow test statistics specified for the considered models (in the dose range of $0-2 \%$ ) were the smallest (Table 3-5). The trends described above were not observed for dry root biomass (Fig. 8). It could be due to the fact that with still

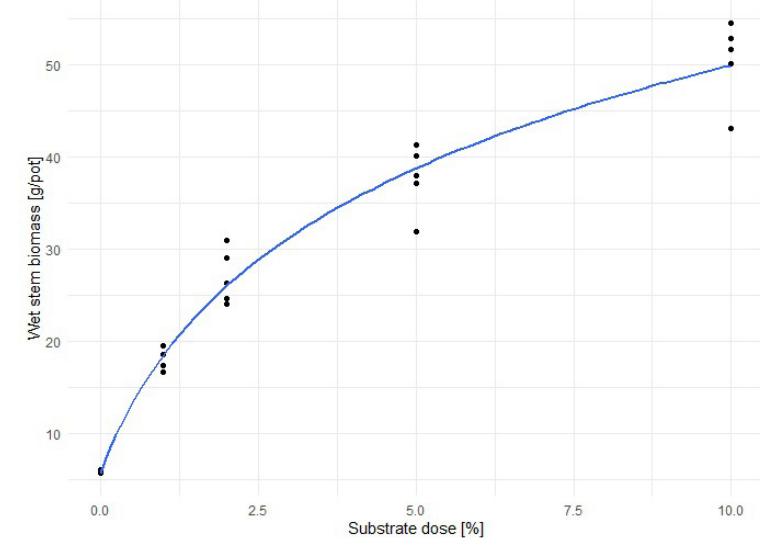

Fig. 5. Dependence of wet stem biomass of maize on the Z-ion substrate dose present in the marginal soil

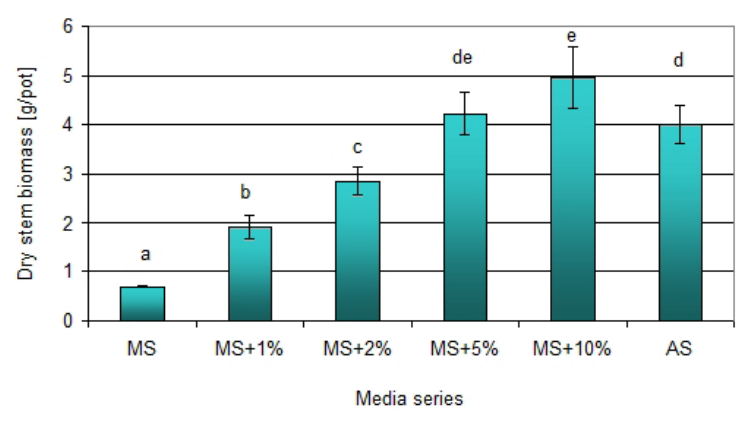

Fig. 2. Dry stem biomass of maize in media series of pot experiment; explanations are the same as under Fig. 1

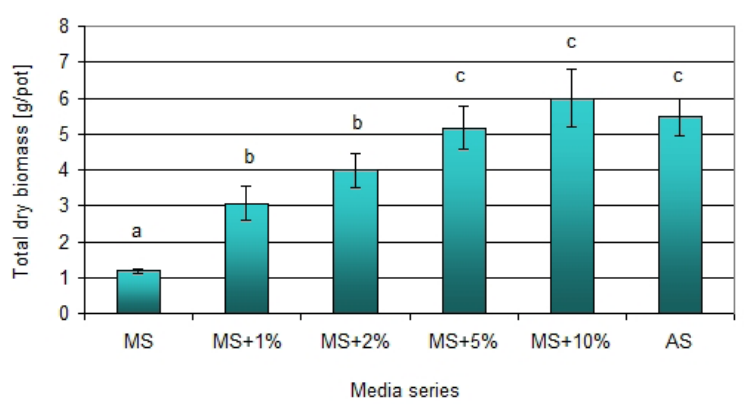

Fig. 4. Total dry biomass of maize in media series of pot experiment; explanations are the same as under Fig. 1

increasing above-ground biomass, the development of the plant root system may be limited by subsequent increasing doses of some nutrients (present in the substrate) - especially by nitrogen [Lityński and Jurkowska 1982, Fageria and Moreira 2011, Yu et al. 2014].

The observed increases in vegetative parameters of maize (dry root and stem biomass) caused by $2 \%$ dose of zeolite substrate were lower than those observed in previous studies where $2 \%$

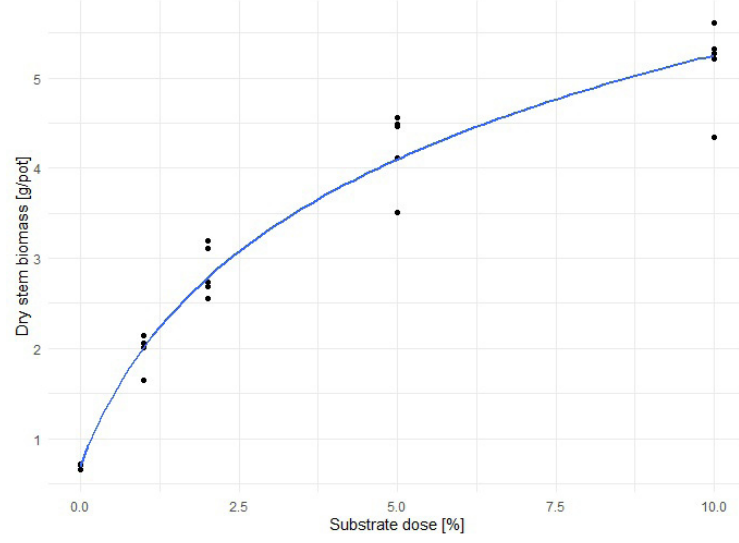

Fig. 6. Dependence of dry stem biomass of maize on the Z-ion substrate dose present in the marginal soil 
Table 3. Parameters of linear and logarithmic regressions for relationship between wet stem biomass of maize and Z-ion substrate dose

\begin{tabular}{|c|c|c|c|c|c|c|}
\hline \multirow{2}{*}{ Parameters } & \multicolumn{6}{|c|}{ Regressions } \\
\hline & 1 & 2 & 3 & 4 & 5 & 6 \\
\hline$a_{1}$ & $10.539^{* * *}$ & $5.957^{*+*}$ & $4.058^{*+*+*}$ & - & - & - \\
\hline$a_{2}$ & - & - & - & $18.981^{* \star *}$ & $17.973^{* \star *}$ & $18.425^{\star \star *}$ \\
\hline$a_{0}$ & $6.355^{* * *}$ & $10.173^{* * *}$ & $13.140^{* * * *}$ & $5.557^{* * *}$ & $5.986^{* * * *}$ & $5.708^{* * * *}$ \\
\hline Observations & 15 & 20 & 25 & 15 & 20 & 25 \\
\hline $\mathrm{R}^{2}$ & 0.959 (95.9\%) & $0.878(87.8 \%)$ & $0.878(87.8 \%)$ & $0.960(96 \%)$ & $\begin{array}{c}0.963 \\
(96.3 \%)\end{array}$ & $0.970(97 \%)$ \\
\hline F Statistics & $305.041^{* * *}$ & $129.775^{\star * *}$ & $165.935^{\star * *}$ & $313.956^{* * *}$ & $474.951^{* * *}$ & $738.064^{* * *}$ \\
\hline$\left|R^{2}{ }_{\text {log }}-R_{\text {lin }}^{2}\right|$ & - & - & - & $0.1 \%$ & $8.5 \%$ & $9.2 \%$ \\
\hline$\left|F_{\text {log }}-F_{\text {lin }}\right|$ & - & - & - & 8.915 & 345.176 & 572.129 \\
\hline
\end{tabular}

Explanations: 1,2,3 - linear regression for substrate dose ranges: 0-2\% (1), 0-5\% (2), 0-10\% (3), 4,5,6 - logarithmic regression for substrate dose ranges: $0-2 \%(4), 0-5 \%(5), 0-10 \%(6), a_{1}-$ the slope for linear regression, $a_{2}$ - the slope for logarithmic regression, $\mathrm{a}_{0}$ - the intercept, $\left|\mathrm{R}_{\log }^{2}-\mathrm{R}_{\operatorname{lin}}\right|-$ the absolute value of the difference between $\mathrm{R}^{2}$ for logarithmic regression and $\mathrm{R}^{2}$ for linear regression, $\left|\mathrm{F}_{\log }-\mathrm{F}_{\operatorname{lin}}\right|-$ the absolute value of the difference between $\mathrm{F}$ for logarithmic regression and $\mathrm{F}$ for linear regression, ${ }^{* * *}$ - parameters statistically significant at $\mathrm{p}<0.01$

Table 4. Parameters of linear and logarithmic regressions for relationship between dry stem biomass of maize and Z-ion substrate dose. Explanations are the same as under Table 3

\begin{tabular}{|c|c|c|c|c|c|c|}
\hline \multirow{2}{*}{ Parameters } & \multicolumn{6}{|c|}{ Regressions } \\
\hline & 1 & 2 & 3 & 4 & 5 & 6 \\
\hline$a_{1}$ & $1.081^{1+*}$ & $0.671^{* * *}$ & $0.412^{+*+*}$ & - & - & - \\
\hline$a_{2}$ & - & - & - & $1.943^{*+* *}$ & $1.990^{* * * *}$ & $1.902^{* * *}$ \\
\hline$a_{0}$ & $0.738^{* * *}$ & $1.080^{*+* *}$ & $1.483^{*+*}$ & $0.658^{* * *+}$ & $0.638^{* * *+}$ & $0.692^{* * *}$ \\
\hline Observations & 15 & 20 & 25 & 15 & 20 & 25 \\
\hline $\mathrm{R}^{2}$ & $0.952(95.2 \%)$ & $0.905(90.5 \%)$ & $0.845(84.5 \%)$ & $0.949(94.9 \%)$ & $0.960(96 \%)$ & $0.963(96.3 \%)$ \\
\hline F Statistic & $256.279^{* * * *}$ & $170.547^{* * *}$ & $125.243^{* *+*}$ & $243.578^{* * *+}$ & $429.732^{*+*}$ & $598.811^{* * *}$ \\
\hline$\left|R_{\log }^{2}-R_{\operatorname{lin}}^{2}\right|$ & - & - & - & $0.3 \%$ & $5.5 \%$ & $11.8 \%$ \\
\hline$\left|F_{\text {log }}-F_{\text {lin }}\right|$ & - & - & - & 12.701 & 259.185 & 473.568 \\
\hline
\end{tabular}

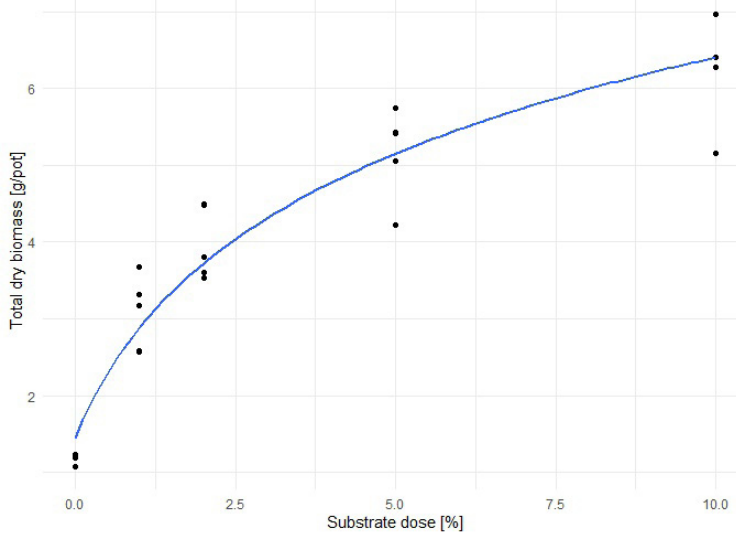

Fig. 7. Dependence of total dry biomass of maize on the Z-ion substrate dose present in the marginal soil

additions of different ion exchange substrates (e.g. Biona ${ }^{\circledR}-312$, Biona ${ }^{\circledR}-111, \mathrm{Mp}$ ) were used to improve the growth of orchard grass [Wasag et al. 2000, Chomczyńska 2013]. The differences in the effectiveness of Z-ion substrate and ion exchange substrates could be caused by varying nutrient

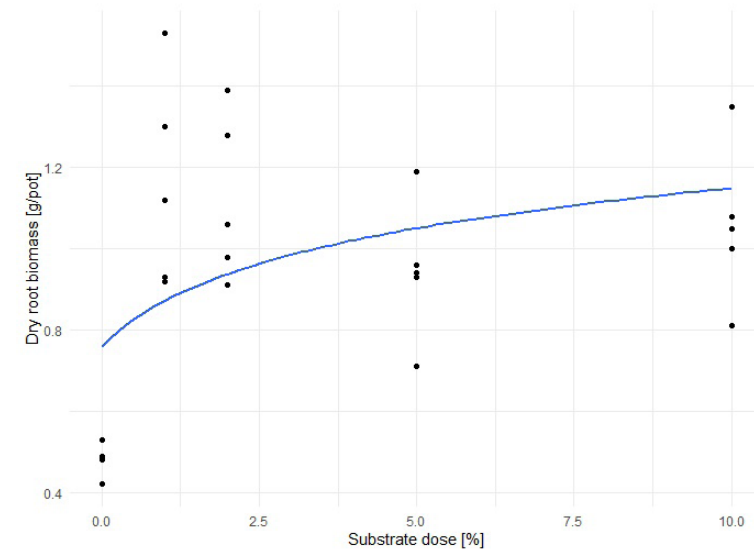

Fig. 8. Dependence of dry root biomass of maize on the Z-ion substrate dose present in the marginal soil

contents in particular substrates (Table 6) or different nutrient demands of the test species (maize, orchard grass).

The comparison of values pertaining to the vegetative parameters of the plants growing on arable soil with those characterizing the plant 
Table 5. Parameters of linear and logarithmic regressions for relationship between total dry biomass of maize and Z-ion substrate dose. Explanations are the same as under Table 3

\begin{tabular}{|c|c|c|c|c|c|c|}
\hline \multirow{2}{*}{ Parameters } & \multicolumn{6}{|c|}{ Regressions } \\
\hline & 1 & 2 & 3 & 4 & 5 & 6 \\
\hline$a_{1}$ & $1.403^{*+* *}$ & $0.722^{2 * * *}$ & $0.436^{*+* x}$ & - & - & - \\
\hline$a_{2}$ & - & - & - & $2.572^{* * *}$ & $2.233^{*+*}$ & $2.064^{* * * *}$ \\
\hline$a_{0}$ & $1.337^{* * *}$ & $1.904^{* * * *}$ & $2.351^{*+* t}$ & $1.204^{* * *}$ & $1.348^{*+*}$ & $1.452^{*+*}$ \\
\hline Observations & 15 & 20 & 25 & 15 & 20 & 25 \\
\hline $\mathrm{R}^{2}$ & $0.883(88.3 \%)$ & $0.795(79.5 \%)$ & $0.771(77.1 \%)$ & $0.916(91.6 \%)$ & $0.917(91.7 \%)$ & $0.925(92.5 \%)$ \\
\hline F Statistic & $97.972^{* * *}$ & $69.831^{*+*+*}$ & $77.504^{* * *+}$ & $141.352^{* * * *}$ & $198.251^{*+*}$ & $285.521^{+* * *}$ \\
\hline$\left|R_{\log }^{2}-R^{2}{ }_{\text {lin }}\right|$ & - & - & - & $3.3 \%$ & $12.2 \%$ & $15.4 \%$ \\
\hline$\left|F_{\text {log }}-F_{\text {lin }}\right|$ & - & - & - & 43.38 & 128.42 & 208.017 \\
\hline
\end{tabular}

Table 6. Comparison of nutrient contents in Z-ion substrate and ion exchange substrates

\begin{tabular}{|c|c|c|c|c|c|c|}
\hline \multirow{2}{*}{ Substrate } & $\mathrm{K}$ & $\mathrm{Ca}$ & $\mathrm{Mg}$ & $\mathrm{N}$ & $\mathrm{P}$ & $S$ \\
\hline & \multicolumn{6}{|c|}{$\mathrm{mmol} / 100 \mathrm{~g}$} \\
\hline Biona $^{\circledR}-111$ & 19 & 204 & 80 & 101 & 18 & 21 \\
\hline Biona $^{\circledR}-312$ & 45 & 222 & 72 & 73 & 11 & 19 \\
\hline $\mathrm{Mp}$ & 18 & 306 & 48 & 77 & 21 & 15.5 \\
\hline Z-ion & 11 & 11.3 & 8 & 32.4 & 10 & 0.14 \\
\hline
\end{tabular}

Table 7. The C:N ratio in above-ground biomass of maize growing on media series in the pot experiment

\begin{tabular}{|l|c|c|c|}
\hline \multicolumn{1}{|c|}{ Media series } & C content [\% d.m.] & N content [\% d.m.] & C:N \\
\hline Marginal soil & 48.00 & 3.14 & 15.27 \\
\hline Marginal soil+1\% Z-ion & 45.54 & 3.18 & 14.33 \\
\hline Marginal soil+2\% Z-ion & 43.96 & 3.08 & 13.05 \\
\hline Marginal soil+5\% Z-ion & 42.28 & 3.24 & 11.81 \\
\hline Marginal soil+10\% Z-ion & 41.40 & 3.51 & 40.34 \\
\hline Arable soil & 44.73 & 1.11 & \\
\hline
\end{tabular}

Explanations: d.m. - dry matter (in $105^{\circ} \mathrm{C}$ ).

growth on marginal soil supplemented with Z-ion substrate should allow to chose the substrate dose that after introducing into marginal soil would give the same plant yield as arable soil. In this analysis, the above-ground biomass of maize should be considered first of all because it is used as feedstock in methane fermentation for biogas production [Nabel et al. 2014, Barbosa et al. 2014, Nabel et al. 2016]. The wet and dry stem biomass of maize growing on arable soil were significantly higher (by $75-111 \%$ ) than those obtained on the marginal soil enriched with $1 \%$ substrate addition (Fig. 1, 2). The yield of above-ground biomass (wet and dry) obtained on arable soil exceeded that observed on marginal soil plus $2 \%$ addition of Z-ion substrate by $16-40 \%$ and difference in dry stem biomass between both considered media series was statistically significant (Fig. 2). Conversely, the wet and dry stem biomass of maize growing on marginal soil with added 5\% substrate did not differ significantly from those obtained on arable soil (Fig. 1, 2). Thus, 5\% addition of Z-ion substrate can be considered as that increasing fertility of marginal soil to the level of selected arable soil of medium quality. Obviously, this observation should be confirmed under field conditions for maize cultivation over longer time period than that established for the presented pot experiment.

While analyzing the results of the presented studies it is worth to pay attention to the C:N ratio in maize stems because this parameter is important for appropriate course of methane fermentation. Literature recommends an operating C: $\mathrm{N}$ ratio ranges of 20-30 [Kainthola et 
al. 2019, Montusiewicz et al. 2008] or 10-25 [Jędrczak 2007] for the materials feeding biogas reactors; however, the optimal $\mathrm{C}: \mathrm{N}$ ratio varies with the type of feedstock to be digested [Li et al. 2011]. The data presented in table 7 indicate that the $\mathrm{C}: \mathrm{N}$ ratio in maize stems decreased along with an increase in Z-ion dose added to marginal soil. The $\mathrm{C}: \mathrm{N}$ ratio in maize biomass growing on marginal soil supplemented with 5\% Z-ion addition was in the range recommended by Jędrczak, but this parameter obtained for plants growing on arable soil was higher than both $\mathrm{C}: \mathrm{N}$ ratio ranges presented in literature. The lower value of the $\mathrm{C}: \mathrm{N}$ ratio in maize biomass in $\mathrm{MS}+5 \%$ series as compared to that obtained in AS series resulted from higher nitrogen content in plant tissue, assuredly caused by introducing nitrogen together with Z-ion substrate into marginal soil.

\section{CONCLUSIONS}

On the basis of the results presented herein, the following conclusions were drawn:

1. Z-ion substrate seems to be an efficient means for fertilization of degraded or marginal soils all its doses introduced into soil influenced the plant growth advantageously, increasing above-ground biomass of maize.

2. Under experimental conditions, in the sixth week of plant growth, a $5 \%(\mathrm{v} / \mathrm{v})$ substrate addition to the marginal soil enabled to achieve the values of vegetation parameters at a level similar to that of the parameters characterizing the plant development on arable land. Thus, at an early stage of plant growth, a 5\% substrate dose can be considered as one allowing a similar course of maize growing on marginal soil as in the case of the selected arable soil.

3. At $5 \%(\mathrm{v} / \mathrm{v})$ substrate dose in soil, the C:N ratio in maize stems reached the value of 13.05 , at which the plant biomass is the feedstock that should ensure the fairly proper course of methane fermentation supplying fuel in the form of biogas.

\section{Acknowledgments}

This work was supported by grant of Lublin University of Technology, No FN-75/IŚ/2019

\section{REFERENCES}

1. Barbosa D.B.P., Nabel M., Jablonowski N.D. 2014. Biogas-digestate as nutrient source for biomass production of Sida hermaphrodita L., Zea mays L. and Medicago sativa L. Energy Procedia, 59, 120-126.

2. Chomczyńska M. 2013. Restoration of degraded soils using ion exchange materials (in Polish). Monografie Komitetu Inżynierii Środowiska PAN, 110, 1-145.

3. Chomczynska M., Pristavko S., Soldatov V., Wasąg H. 2014. The influence of ion-exchange substrates on grass growth in sandy soils. Journal of Plant $\mathrm{Nu}$ trition and Soil Science, 177, 438-442.

4. Chomczynska M., Soldatov V., Wasag H., Turski M. 2016. The effect of ion exchange substrate on grass root development and cohesion of sandy soil. International Agrophysics, 30, 293-300.

5. Comparetti A., Febo P., Greco C., Orlando S. 2013. Current state and future of biogas and digestate production. Bulgarian Journal of Agricultural Science, $19,1-14$.

6. Devore J.L. 2011. Probability and statistics for engineering and the sciences. Brooks/Cole Cengage Learning, Boston.

7. Fageria N.K., Moreira A. 2011. The role of mineral nutrition on root growth of crop plants. In: D.L. Sparks (ed.), Advances in agronomy, Academic Press, San Diego, vol. 110: 251-331.

8. FAO. 2009. The State of Food Insecurity in the World Economic Crises - impacts and Lessons Learned.

9. Fritsche U.R., Sims R.E.H., Monti A. 2010. Direct and indirect land-use competition issues for energy crops and their sustainable production - an overview. Biofuels, Bioproducts and Biorefining, 4, 692-704.

10. Igliński B., Buczkowski R., Cichosz M. 2009. Bioenergetic technologies (in Polish). Wydawnictwo Naukowe Uniwersytetu Mikołaja Kopernika, Toruń.

11. Jędrczak A. 2007. Biological waste treatment (in Polish). Wydawnictwo Naukowe PWN, Warszawa.

12. Kainthola J., Kalamdhada A.S., GoudaV.V. 2019. Optimization of methane production during anaerobic co-digestion of rice straw and Hydrilla verticillata using response surface methodology. Fuel, 235, 92-99.

13. Kosandrovich E.G., Soldatov V.S., Krasinskaya T.V., Kosandrovich S.Yu., Ionova O.V., Yezubets H.P., Vonsovich N.V., Melnikov I.O., Saprykin V.V. 2019. Universal nitrate free nutrient substrates based on chemically modified natural clinoptilolites. III International symposium on growing media, composting and substrate analysis, Abstracts, 88.

14. Koszel M., Lorencowicz E. 2015. Agricultural use of biogas digestate as a replacement fertilizers. 
Agriculture and Agricultural Science Procedia, 7, 119-124.

15. Kościk B. 2003. Energetic plants (in Polish). Wydawnictwo Akdemii Rolniczej w Lublinie, Lublin.

16. Lewandowski W.M., Ryms M. 2013. Biopaliwa. Proekologiczne odnawialne źródła energii. Wydawnictwo WNT, Warszawa.

17. Li Y., Park S.Y., Zhu J. 2011. Solid-state anaerobic digestion for methane production from organic waste. Renewable and Sustainable Energy Reviews, $15,821-826$.

18. Lityński T., Jurkowska H. 1982. Soil fertility and plant nutrition (in Polish). PWN, Warszawa.

19. Montusiewicz A., Lebiocka M., Pawłowska M. 2008. Characterization of the biomethanization process in selected waste mixtures. Archives of Environmental Protection, 34, 49-61.

20. Nabel M., Barbosa D.B.P., Korsch D., Jablonowski N.D. 2014. Energy crop (Sida hermaphrodita) fertilization using digestate under marginal soil conditions: A dose-response experiment. Energy Procedia, 59, 127-133.

21. Nabel M., Temperton V.M., Porter H., Lucke A., Jablonowski N.D. 2016. Energizing marginal soils - The establishment of the energy crop Sida hermaphrodita as dependent on digestate fertilization, NPK, and legume intercropping. Biomass and
Bioenergy, 87, 9-16.

22. Ostrowska A., Gawliński S., Szczubiałka Z. 1991. Methods for analysis and evaluation of soil and plant properties (in Polish). Instytut Ochrony Środwiska, Warszawa.

23. Soldatov V.S. 2019. Artificial soils on the base of synthetic ion exchangers. III International symposium on growing media, composting and substrate analysis, Abstracts, 28.

24. Wasąg H., Pawłowski L., Soldatov V.S., Szymańska M., Chomczyńska M., Kołodyńska M., Ostrowski J., Rut B., Skwarek A., Młodawska G. 2000. Restoration of degraded soils using ion exchange resins. Raport (in Polish). Politechnika Lubelska, Lublin.

25. Wołek J. 2007. Introduction to statistics for biologists (in Polish). Wydawnictwo Naukowe Uniwersytetu Pedagogicznego w Krakowie, Kraków.

26. Wooldridge J.M. 2009. Introductory econometrics: a modern approach. South-Western Cengage Learning, Mason.

27. Yu P., White P.J., Hochholdinger F., Li C. 2014. Phenotypic plasticity of the maize root system in response to heterogeneous nitrogen availability. Planta, 240, 667-678.

28. Zuur A.F. 2009. Mixed effects models and extensions in ecology with R. Statistics for biology and health. Springer, New York. 